\title{
Difficulties of Learning EFL in KSA: Writing Skills in Context
}

\author{
Taj Mohammad $^{1} \&$ Zoheb Hazarika $^{1}$ \\ ${ }^{1}$ Najran Univeristy, KSA \\ Correspondence: Taj Mohammad, Najran Univeristy, KSA. E-mail: tajmohd09@gmail.com
}

Received: March 27, 2016

Accepted: April 20, 2016 Online Published: May 25, 2016

doi:10.5539/ijel.v6n3p105

URL: http://dx.doi.org/10.5539/ijel.v6n3p105

\begin{abstract}
This study is an in-depth effort to investigate issues usually faced by EFL learners in writing skills. Fifty students of Preparatory Year Program (from different sections) Najran University were randomly selected to illicit their opinion on writing skill using Likert's 5 scale (always, usually, sometimes, rarely never) questionnaire. In addition, fifty writing samples from first and second midterms of PYP were also selected. The study analyses the writing samples mainly focusing on with special reference to capitalization, punctuation, language use (grammar) and spelling and their impact on other items of language like articles, preposition, coherence, cohesion etc. Contrastive analysis of students' writing samples and questionnaire prove that students commit mistakes, though unconsciously, in writing. While conducting data analysis using students' writing samples, it was observed that students used ways to pass an exam i.e. memorize the writing answer(s)/paragraph(s) rather than the proper approaches to developing/learning most common writing strategies when writing an answer. In the end, this study offers some remedial measures for writing problems of Arab EFL learners.
\end{abstract}

Keywords: analysis of writing samples, diagnosing students' perceptions, EFL practices

\section{Introduction}

There is need for a global language that could be used as a lingua franca among international communities. This need doesn't confine only to academic circles but also to business and personal circles of the people. It connects the people from all over the world and provides them an opportunity to be familiar with each other (Crystal, 2003). It is quite obvious that Crystal is indicating English language here. It is need of today's world. When one talks about language, it can be broadly categorized into four skills namely listening, speaking, reading and writing. All the skills are equally important in a language but writing becomes more important in academic disciplines because it is one of the most important means to examine the performance of students in their respective fields of study. Javid \& Umer (2014) opinionate that the importance of writing springs from its being primary means by which students are able to show their progress and academic development to their instructors. Their competence in other skills depends primarily on their writing skills. As Javid \& Umer (2014, p. 165) quoted Fageeh (2011) that to learn a language students are mostly dependent on writing as "integral skill to language learning."

Moreover, writing is more important because it is a thinking tool and helps in the development of a language as Bjork \& Raisanen (1997 as quoted in Javid \& Umer, 2014, p. 164) argue that "we highlight the importance of writing in all university curricula not only because of its immediate practical application, i.e. as an isolated skill or ability, but because we believe that, from a broader perspective, writing is a thinking tool. It is a tool for language development, for critical thinking and, extension, for learning in all disciplines". To convey ideas and facts in a clear and accurate way requires appropriate written language (Hashim, 2011).

There is no doubt in the fact that writing is a tool for the creation of ideas and the consolidation of the linguistic system by using it for communicative objectives in an interactive way. Thus it implies the successful transmission of ideas from an addresser to an addressee through a text, and this exchange of information becomes a powerful means to motivate and encourage the development of writing skills. Writing is often a challenge for EFL learners as it is considered to be the most painstaking and challenging language skill. The researchers, with experience of several years of teaching EFL in Saudi Arabia, have been witnesses to this challenging task. It has been a challenging task for EFL teachers because students, as observed in their writing samples do not take much interest in writing either for academic, professional or personal purposes. Moreover, writing requires an in-depth understanding of target language. In a way, it is an amalgam of different other skills 
like reading, listening etc. That's why students hardly feel motivated for writing. Motivation plays a very important role in developing any skill. Lack of motivation is one of the most important factors for the poor performance of Arab learners in writing assignments. Bacha (2002, p. 161) suggested that it might be due to the fact that the students are not motivated to develop their writing and that "L2 writers are known to face problems in developing their writing skills at the university level. These problems are even more accentuated with L1 Arabic non-native speakers of English in required English composition courses". The students who always try their best to compose an impressive paragraph feel demotivated when they cannot achieve what is expected of them. They are likely in a need of receiving proper instruction on how to compose an effective text. When they have to write on different non-interesting topics in their exams in English, their performance hardly reaches satisfactory level (Murshidi, 2014).

In pursuit of learning EFL, students face immense impediments in writing, especially in capitalization, punctuation, language use, tenses, preposition, spelling etc. The same issues have been raised by Khan (2011) as he mentions that they face several problems in phoneme clusters, spellings, grammar, mistakes due to L1 interference, structure, doubling of subjects, doubling of preposition, tenses, articles, appropriate vocabulary, incorrect use of prefixes \& suffixes etc.

There is one study conducted by Ridha $(2012$, p. 44) on Iraqi college students where she investigated errors in English essay writings of EFL students. The errors were categorized according to the following taxonomy: grammatical, lexical, semantic, mechanics, and word order types of errors. The grammatical and the mechanical errors were the most serious and frequent ones. The most of the students' errors were led by the Arabic interference.

This aggravated situation in writing is an amalgamation of many factors like lack of exposure, learner's poor background, mother tongue interference, lack of language learning environment and lack of motivation. Al-Jarf (2010, p. 12) mentions about Lado (1957) in his study "that errors in the second language (L2) are caused by the interference of the student's native language. Such errors reflect the student's inability to separate L1 and L2."

In an EFL situation, most of the students rely on memorizing rather than learning language. While conducting data analysis using students' writing samples, it was observed that students used ways to pass exam i.e., memorize the writing answer(s)/ paragraph(s) rather than the proper approaches to developing/learning most common writing strategies when writing an answer. It is researched that memorization has been a traditional practice of students. It may also be opined that traditional method of teaching EFL encourages students to memorize rather than learning a language. It is a big obstacle in learning a language that thwarts and affects their writing practices. Therefore, some remedies need to be suggested in form of classroom activities based on practical and real life situations. This will help EFL students discourage memorizing the language items and minimize language errors in their writing assignments.

In order to be more focused and productive, the researchers have categorized students' problems in four major areas like capitalization, punctuation, language use, and spelling. Students' questionnaire contained the same areas. The study analyses the writing samples mainly focusing on capitalization, punctuation, language use (grammar) and spelling and their impact on other items of language like articles, preposition, conjunction, coherence and cohesion etc. Rass (2015, p. 51) mentions a study by Barry (2014) who "analyzed the writing samples of 38 Saudi students, 32 males and 6 females, attending a pre-academic program at Oakland University in Michigan. Data analysis included several categories like use of conjunctions, use of conventions of English expression and word order. Findings reveal excessive use of conjunctions, especially "and".

The present research delineates this aggravated situation particularly of students of writing skills courses at Preparatory Year, Najran University. It also provides recommendations which will inculcate in developing writing skill among EFL learners.

\section{Literature Review}

Literature concerning ELT in general is available in a very large number, but pragmatic researches conducted on writing are comparatively very few. Some of the researchers have done their research work on identifying the problems of the Arab EFL learners in four language skills. However, Arab learners of English encounter problems in both speaking and writing. This fact has been clearly stated by many researchers like Abdul Haq (1982). For example, Yemeni students learn English in their country where native language is Arabic. Foreign language teachers have long been mystified by a range of overflowing psycho-linguistic theories.

A lot of problems dealing with Arab students have been recognized in their course of studying English language. For example, the work of Abdul Haq (1982) concluded that most Arab students usually face problems in writing 
skills. One significant study by Haq (1982) stated that most Arab students usually have problems in their writing skills. In his study, Haq (1982) also argued that most English instructors and University officials were concerned about the continuous deterioration in English language among the students. In his study Khan (2011) mentions Zughoul (1984) where he endorsed the findings of Haq (1982) by concluding that most Jordanian students in EFL classes usually commit gross lexical errors in spoken English.

They lack proper knowledge of syntax and spelling rules. They also have difficulty in expressing themselves. Weakness of English language learners is also due to lack of knowledge of the school graduates when they join university. It may also be because of curriculum as well as teaching methodologies. No environment of English language and poor motivation level can also be a cause of weakness of English language (Khan, 2011).

While reviewing the above research works, it has been observed that most of the researchers have identified problems of Arab EFL learners, but very few have given the remedial measures and solutions for these problems. This study specifically focuses on the problems of the four major areas of capitalization, punctuation, language use (grammar) and spelling in writing among the students of writing skills courses at Preparatory Year, Najran University. The present research attempts to suggest techniques, methods and elucidation to improve the major problems faced by Arab / Saudi learners in general and Najran University in particular. The researchers have tried to suggest some useful exercises for the students to improve these areas of writing. This study also attempts to provide some practical remedies and suggestions for the above mentioned problems.

\section{Research Objectives}

1) To critically analyze students' writing samples and focus on the problems like capitalization, punctuation, language use and spelling

2) To critically diagnose students' perception on the above mentioned writing problems

3) To suggest some remedial recommendations on the basis of findings

\section{Context of the Study}

This study was conducted in the first semester of academic year 2014 at PYP department of Najran University, KSA. In the first semester, students are taught Listening, Speaking, Reading and Writing as courses of Level 1. The students who successfully complete the program are promoted to level 2. In second semester, level 2, they are taught integrated skills like General English and Technical Writing. The study is conducted on level 1 students so that it could be a guiding force when they are promoted to level 2 . This research analyzes the writing samples of the students at PYP form level 1. It tries to focus on the problems EFL learners face especially in writing. As Calhoun (2002) describes action research as studying what's happening in a school, deciding if improvement in instruction is needed, examining the effects of what was tried, and then beginning the process again. This process is utilized in the following study. At the bottom of this process was a sincere effort to improve our ability to teach writing. The study provides some suggestions in the form of recommendations on how to improve the teaching of writing.

\section{Methodology}

\subsection{Pilot Study}

To ensure the validity of the survey, it was first piloted by 10 EFL instructors teaching writing for at least four years. Their feedback was useful for modifying some items. The survey was also given to four Asst. Professors and Associate Professors to examine its validity. Some items were modified as per their suggestions so as to achieve the content validity. Later on, the questionnaire was translated into Arabic so that students can understand contents.

\subsection{Participants}

Fifty students were selected for this study. The study was conducted at the end of the semester. In a way, all students had already spent around six months at NU and had appeared in two midterm and several quizzes and progress tests in the class. Students were randomly selected from different writing sections and were given questionnaires (Arabic version) on writing in order to know their opinions on the four sections covered in the study.

\subsection{Tools}

Questionnaire (Arabic translation) was used as a means to collect students' opinion on the common writing problems viz. problems of capitalization, punctuation, language use (grammar) and spelling (see Appendixes A \& B). As Jung, Osterwalder, \& Wipf (2000) are of the opinion about Likert scale that, "this was the only 
assessment instrument I found that was practical for the classroom" (Jung, Osterwalder, \& Witpf, 2000, p. 2). The questionnaire used likert scale of agreement (ranging from 1 which means "never" to 5 which means "always"). Two scales (never and rarely) were merged for the convenience of the interpretation of data. Writing samples were collected from the first midterm and second midterm examination answer sheets. These samples were used to diagnose the actual problems students face during examination.

\subsection{Procedures}

50 questionnaires (containing 4 statements) were distributed among all students. 30 questionnaires which were given serious attention by the students were finally selected for the study. Incomplete questionnaire or the ones with the same values against each item were not included in the study. In order to make their responses more reliable, the questionnaire was translated into Arabic. The students were first described the importance of this study and then given enough time to fill in questionnaire. While analyzing the questionnaires, the researchers found that most of the students were not aware of the fact that they had problems in capitalization, punctuation, language use (grammar) and spelling.

Students' fifty writing samples from first and second midterm were also selected randomly. Out of 50 samples, 30 samples which could be exploited most to the investigation of researchers were taken into consideration. To the surprise of the researchers, most of the students' writing samples had several severe problems. Only four of them (capitalization, punctuation, spelling and language use) are presented for this study to examine and to offer the suggestions and relevant remedies to improve the teaching writing instructions and/or to develop the writing skills among learners.

\section{Analysis of Data}

The data analysis has been divided into two parts: the first will contain a detailed analysis on the responses of the questionnaire and the second one will be a detailed analysis on the writing samples followed by a detailed discussion on both of them. Four samples are attached on Capitalization, Punctuation, Language use (grammar) and Spelling namely as writing samples 1,2,3 and 4 .

\subsection{Analysis of Students' Questionnaire}

The following figures have been analyzed carefully to present the students' opinion on every single writing problem i.e. capitalization, punctuation, language use and spelling. The students were asked a question on each of the problem areas:

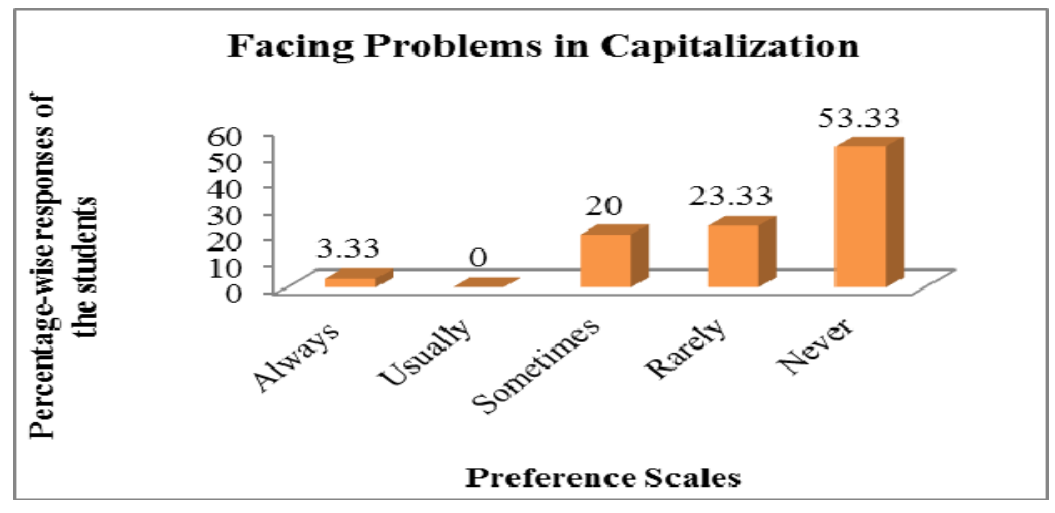

Figure 1. Problems in capitalization

The researchers asked a question regarding the capitalization problems in writing. 3.33\% of the students said they always faced problems with capitalization. There was no value assigned against the scale 'usually', here $20 \%$ of the students admitted that they sometimes had problems in capitalization. $23.33 \%$ of the students opinionated they rarely faced problems with capitalization. Though respondents (see Figure 1) gave different responses, most of them (53.33\%) agreed that they never had problems in capitalization. If the two scales (rarely and never) which are very close in meaning are merged, total percentage would be $23.33+53.33=76.66$. It means there is a big number of students who said they did not have problem in capitalization. 


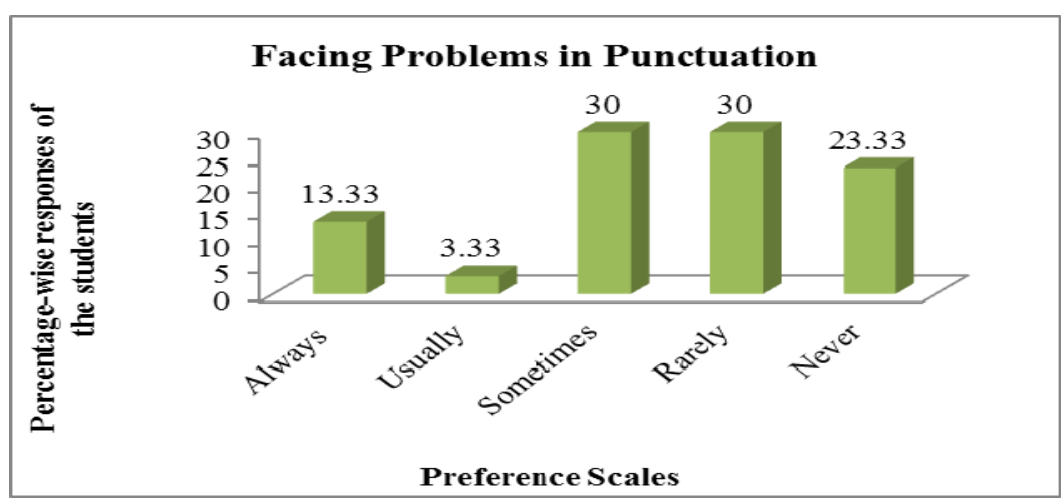

Figure 2. Problems in punctuation

The researchers asked next question on problems in punctuation. $13.33 \%$ of the students said they always had problems with punctuation. $3.33 \%$ of the students admitted that they usually had problems in punctuation. $30 \%$ of the students opinionated they sometimes faced problems with punctuation. Though respondents (see Figure 2) gave different responses, a significant number of students $(23.33 \%)$ agreed that they never had problems in punctuation. If the two scales (rarely and never) which are very close in meaning are merged, total percentage would be $30+23.33=53.33$. It means there is unavoidable number of students who said they did not have problem in punctuation.

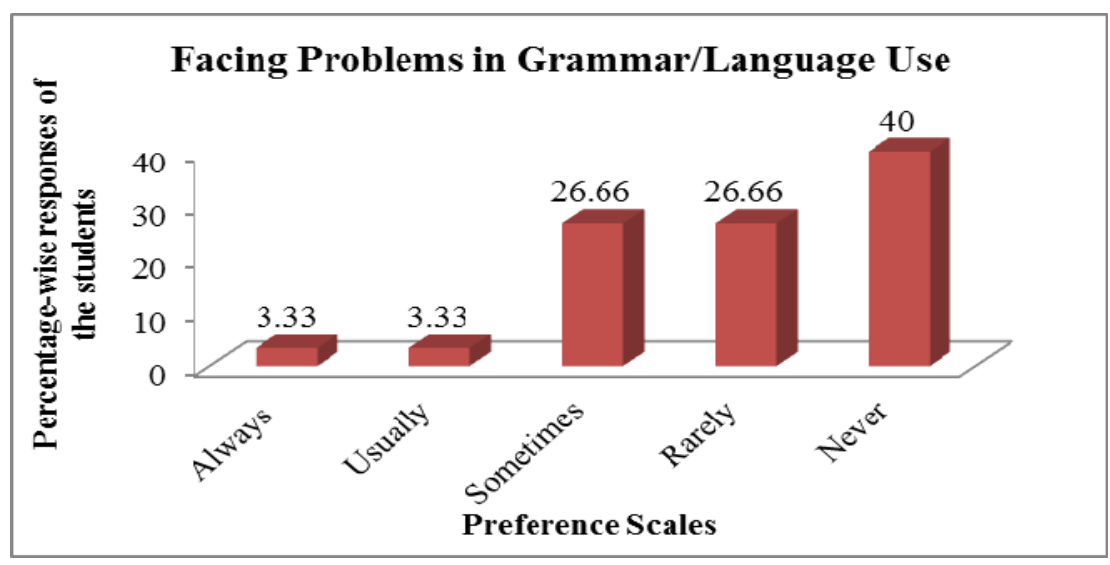

Figure 3. Problems in grammar/language use

The researchers asked next question on problems in grammar and language use. $3.33 \%$ of the students said they always encountered problems with grammar and language use. The same number $(3.33 \%)$ of the students admitted that they usually had problems in grammar and language use. $26.66 \%$ of the students opinionated they sometimes had problems with grammar and language use. The same number of students $(26.66 \%)$ had an opinion that they rarely faced problems in grammar and language use. Though respondents (see Figure 3 ) gave different responses, a significant number of students $(40 \%)$ agreed that they never had problems in grammar and language use. If the two scales (rarely and never) which are very close in meaning are merged, total percentage would be $26.66+40=66.66$. It proves there is a large number of students who said they did not have problems in grammar and language use. 


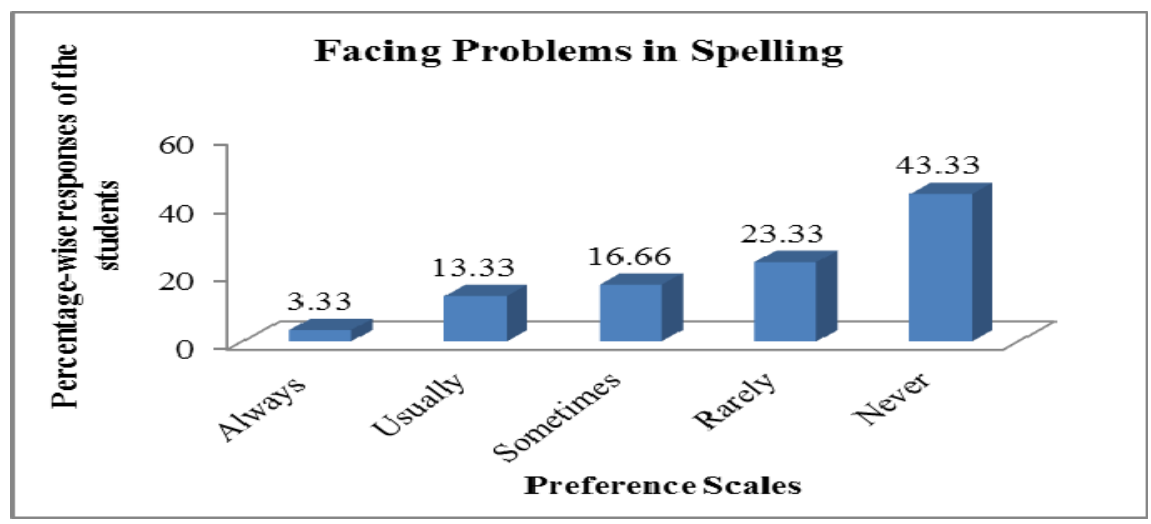

Figure 4. Problems in spelling

The researchers asked last question on problems in spelling. 3.33\% of the students said they always had problems with spelling. $13.33 \%$ of the students accepted that they usually had problems in spelling. $16.66 \%$ of the students opinionated they sometimes had problems with spelling. $23.33 \%$ of the students had an opinion that they rarely faced problems in spelling. Though respondents (see Figure 4) gave different responses, a significant number of students $(43.33 \%$ ) agreed that they never had problems in spelling. If the two scales (rarely and never) which are very close in meaning are merged, total percentage would be $23.33+43.33=66.66$. It proves there is a big number of students who said they did not have problem in spelling.

\subsection{Analysis of Students' Writing Samples}

\subsubsection{Writing Sample 1. Problems in Capitalization}

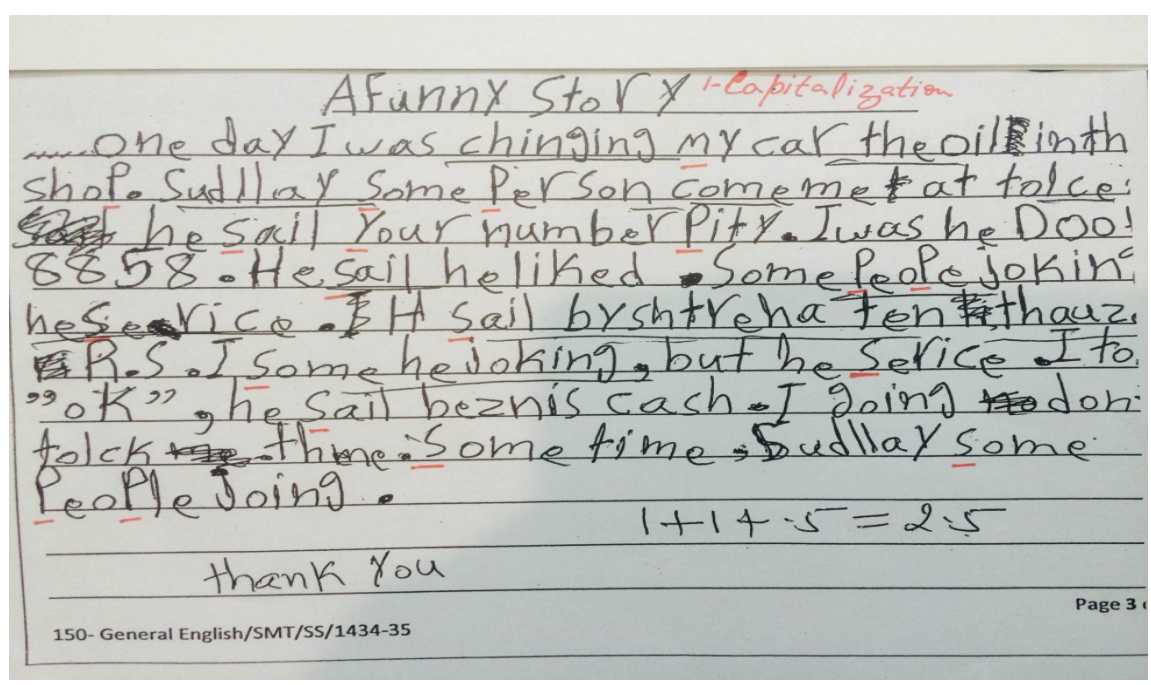

As shown in writing sample-1, most of the students had problems in capitalization. The student writes pronoun 'My' with a capital letter in the middle of the first sentence of the paragraph. In the same sentence he writes 'shoP' where last letter of the word shop is capitalized. In the second sentence, he writes the common nouns: 'Some' and 'Person' with a capital letter in the middle of a sentence. In the third sentence, he writes verb 'Sail', pronoun 'Your' and adjective 'Pity' with a capital letter. They did not know that a new sentence must be started with a capital letter. In sentence 5, he again writes verb 'Sail' with a capital letter. In sentence 6, he misspells the noun 'PeoPe' for people and writes ' $\mathrm{P}$ ' in capital letter. In the same sentence, he writes the noun 'Service' with a capital letter. Then again in sentence 7, he writes 'Sail' with a capital letter. In sentence 8, he writes 'Some' and 'Service' with a capital letter. Again in Sentence 9, he writes 'Sail' with a capital letter. In the last sentence, the student again writes 'Some' with a capital letter. In the same sentence, he writes 'PeoPle' with capital 'P'. 
6.2.2 Writing Sample 2. Problems in Punctuation

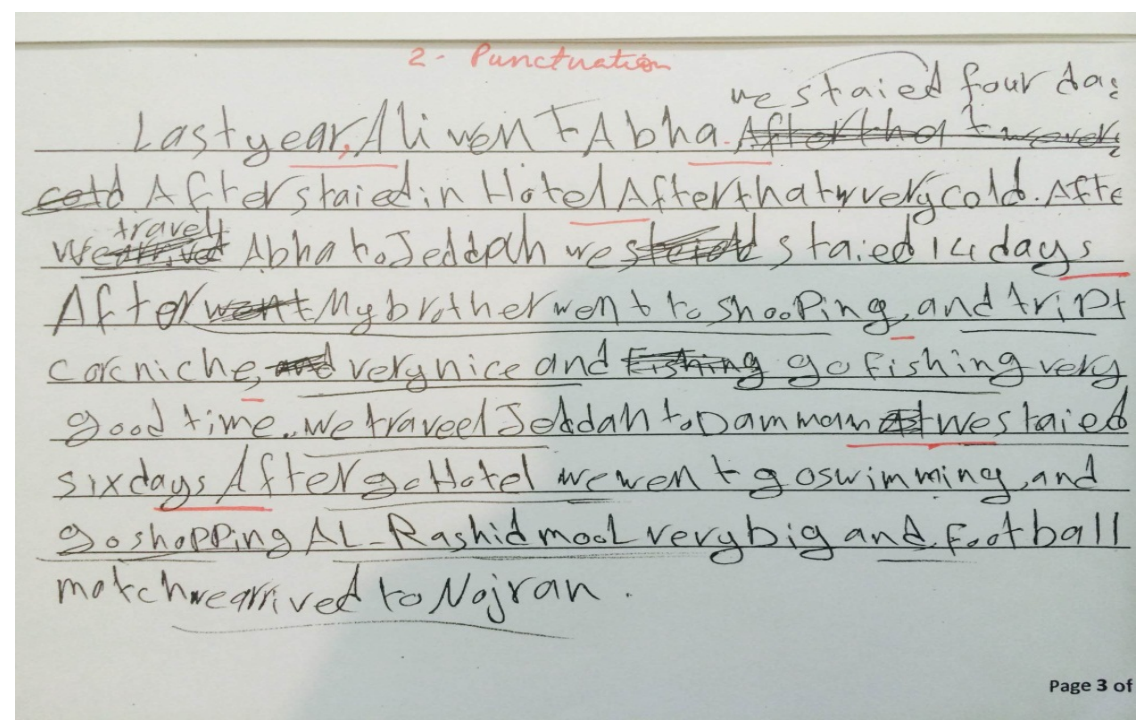

As shown in writing sample-2, at the end of sentence 2, no (.) is used. Sentence 3 is obscure. At the end of sentence 4 , no (.) is used. In sentence 5 , commas are not used at their proper places. At the end of sentence 6 , no full stop is used. At the end of sentence 7, no full stop is used. Sentence 8 is obscure and commas are not used at proper places.

\subsubsection{Writing Sample 3. Problems in Language Use/Grammar}

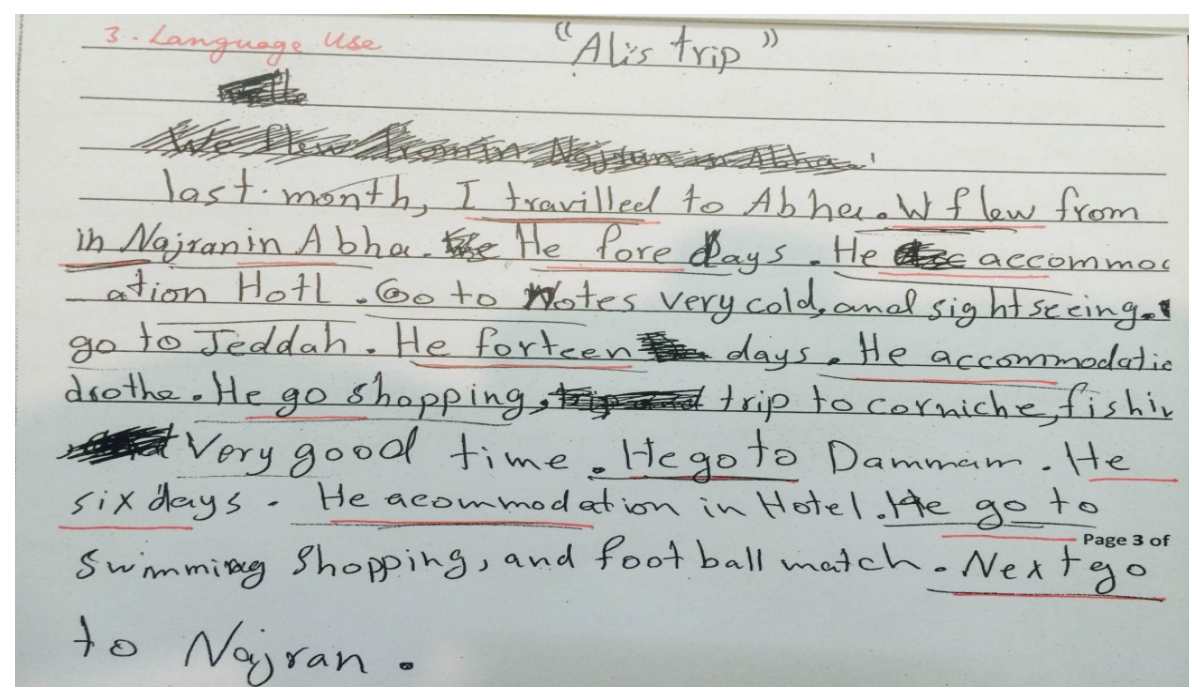

As shown in writing sample-3, student misspelled the verb 'travilled'. In sentence 2, student was not able to write pronoun 'we' and preposition 'in' properly. In sentence 3, helping verb was not used. In sentence 4, no verb is used. Sentence 5 is obscure. In sentence 6 again, helping verb is not used. In sentence 7, no verb is used. In sentence 8 , proper from of verb 'go' is not used. In sentence 9, no verb is used. In sentence 10 , no verb is used. In sentence 11, no proper form of verb according to tense is used. In the last sentence 12, no subject is used. The form of verb 'go' is also misused. There is also a wrong use of preposition 'in'. The expression 'from in Najran in Abha' is very confusing. Rather it should be 'from Najran to Abha'. 


\subsubsection{Writing Sample 4. Problems in Spelling}

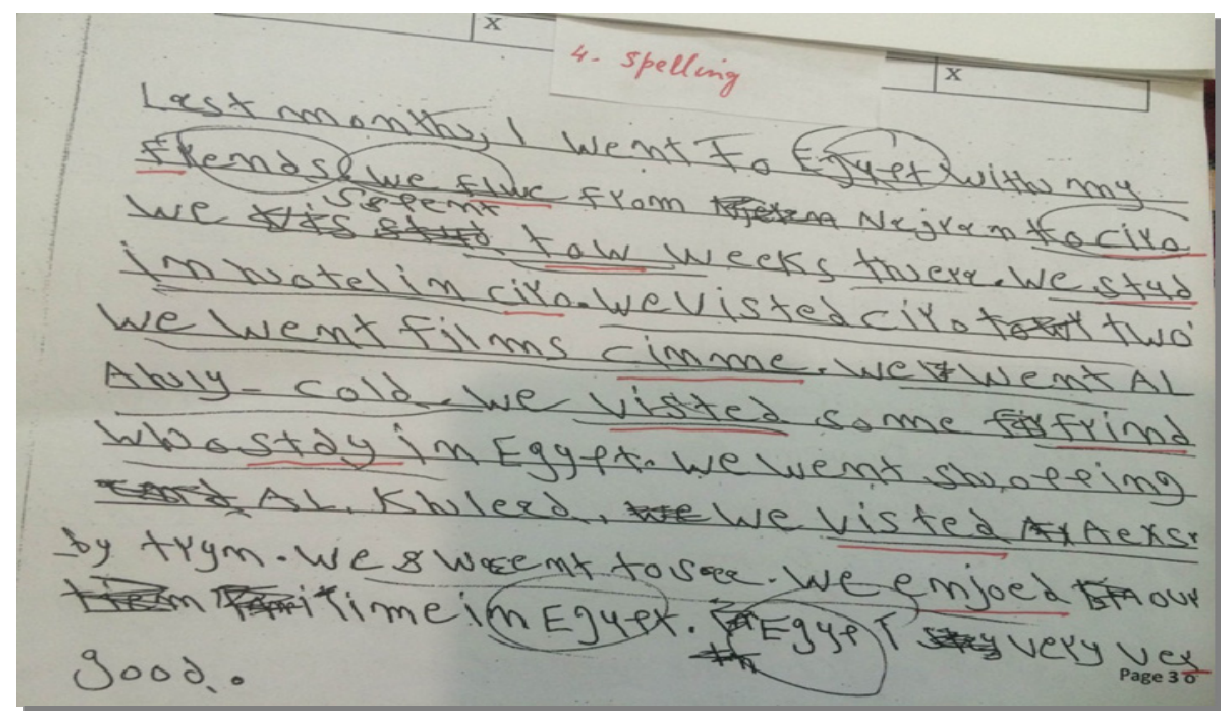

As shown in writing sample-4, most of the students have problems in spelling. In sentence 1 of the paragraph, students misspelled the noun 'friends'. In the second sentence, he misspelled the verb 'flwe' and noun 'Ciro'. In the third sentence he misspelled adverb of number 'tow'. In sentence 4, he misspelled the verb 'stud' and 'ciro' in the same sentence. In sentence 5, he misspelled the noun 'cinme'. In sentence 7, he misspelled the verbs 'visted', 'stdy' and noun 'frind'. In sentence 9 he repeated the same mistake 'visted'. In sentence 11, he misspelled the verb 'enjoed'.

Apart from these samples, there were many other samples containing serious mistakes in writing. All of them were not feasible to be used here. The researchers found that other items of language had a direct impact because of lack of knowledge in four above mentioned areas. For example, students made serious mistakes in the use of Article. They were confused with definite and indefinite articles. They unnecessarily capitalized articles. Students were also confused with the use of prepositions. They did not know the proper use of preposition. Either they were confused with the selection of preposition or with placing it appropriately in a sentence. Students were also confused with auxiliary and main verb. They did not know how to use perfect tense and perfect continuous tense. These errors can be specially attributed to GT method as there is no perfect and perfect continuous tense in Arabic language. As discussed above, students are much influenced by their mother tongue is proved by the writing samples of students. In some of the writing paragraphs, students were lacking coherence and cohesion. But these paragraphs were the original ones though with serious mistakes. As most of the paragraphs were memorized, they had the same contents and same pattern of mistakes.

\section{Discussion}

Comparative analysis of students' response for question 1 and writing sample shows that a highest percentage of the students $(53.33 \%)$ agree that they never have problems in capitalization while the analysis of writing sample of the students reveals they always struggle with capitalization (See Figure 1 and writing sample-1). It shows that students are not even aware of the fact that they commit mistakes in capitalization. They, unconsciously, make mistakes while writing a paragraph. This analysis shows that students need to develop awareness regarding the use of capitalization. Realization of one's mistake is the first step in its correction.

In case of punctuation, the analysis reveals that $23.33 \%$ of students are comfortable with the use of punctuation. $30 \%$ of the students rarely faced problems in punctuation. If these two scales are merged, there will be $53.33 \%$ of students who think they do not face issues in punctuation at all. The study of samples gives a complete opposite idea to what students answered in questionnaire. (See Figure 2 and writing sample-2).Writing samples of most of the students had severe problems in punctuation. Students do not know even the basic rules of punctuation though it has been part of their school curriculum. It proves that nothing substantial is going on in schools. Because of this poor back ground in English, most of the students fail to perform better despite tireless efforts of the teachers at PYP, Najran University.

The analysis of students' ability to use language and grammar shows that they have many problems in expressing 
ideas even if they are given controlled writing paragraph. There is no correct grammatical structure used in the paragraph. The sample of students' writing scripts shows that out of 13 sentences, only six sentences are somewhat meaningful with a few grammatical mistakes (see writing sample-3). It shows students are not familiar even with basic grammar rules. The analysis of writing samples is very discouraging. Nevertheless $40 \%$ of the students agree that they never have problems in using language and grammar while $26.66 \%$ of students boasted they rarely had problems in language or grammar use. (See Figure 3) It is a very alarming situation that students are not even aware of the fact that their basic grammar is too poor. This ignorance of their mistakes makes them further move on the path of committing errors as analyzed above.

In case of spelling, the analysis of writing samples also contrasts to the opinion of the students as depicted in the questionnaire. Writing sample is full of spelling mistakes (in words) while they have not accepted the same in the questionnaire. For example, students are usually confused with 'p' and 'b' as 'p' sound is not found in Arabic alphabet. This confusion often leads to spelling errors. Bebout (1985) is of the opinion that foreign speakers' mispronunciation of English is a recognized cause of spelling errors. The former, for example, highlights problems Arabic learners of English have with the 'mirror' shaped letters(e.g. p and q) and comment on the difficulties which stem from the fact that Arabic is written from right to left (thus learners may write crwon rather than crown). It seems that spelling errors that Arab learners make are linked to the impact of their first language. Thus, it is essential for Arab instructors and stakeholders to consider this dilemma explicitly. Teachers should help students "acquire knowledge about the sound-letter relationships" (Cordewener et al., 2015, p. 107).

This reveals either students are not aware of these sorts of mistakes or their attention is never invited to it (see Figure 4 and writing sample-4). It may be because of examination fury that they commit mistakes. It may also be a result of hurry and worry students have in examination halls. It may be one of the reasons of the contrastive response of the questionnaire that students were reluctant to admit their mistakes or they made the mistakes unconsciously.

The analysis demonstrates the significant differences in the information obtained from students' writing samples and the data obtained from questionnaires based on their perception about their performance. Another noticeable point observed during analysis is the variation in claimed control and actual performance. This can be attributed to the lack of background knowledge of the students in foreign language.

An overall analysis of the writing samples of students demonstrates that the same answers/write ups in most cases are repeated. Most of the samples have same error patterns. They have same sentence structure and patterns with same vocabulary. It invites researchers' attention towards the fact that most of the students have written memorized paragraphs. They expected the same paragraph to be part of examination. They vomited in the examination hall whatever they memorized in a particular course. It seems that this is a traditional practice as students have been doing this since their school days. English is not medium of instructions in primary classes. Students encounter English in higher studies. Khan (2011) has also diagnosed the same problem as he says there are so many factors that affect the teaching-learning process in EFL context in general and KSA in particular. The students face problems in learning due to the reason that they don't study English in early stages and don't use English as medium of instruction except in certain higher education courses. Further, environment and family background play vital role in success of learning process.

Because of poor background in English, students hardly make efforts to learn the language rather they prefer to pass exam by memorizing certain important questions in the examination. Teachers should encourage students to come up with their creative ideas rather than mugging up expected/repeated paragraphs. Teachers must use modern methods and techniques of teaching in the classroom. Javid \& Umer (2014) have reported that use of traditional teaching methods is reportedly a major cause for their weak writing and it is strongly recommended that the faculty members should exploit modern teaching techniques and the classrooms should be provided with the latest teaching aids to ensure enhanced learning possibilities.

Keeping in mind the fact, it is suggested that traditional methods of teaching must be discouraged. There must be a change in the examination pattern. Same questions should not be repeated specially the paragraph writing.

\section{Recommendations}

Analysis of students' questionnaire and the writing samples reveals that there is a huge discrepancy in their claimed control and actual performance. As the data shows, this trend is unanimously seen in all the four major segments of capitalization, punctuation, grammar/language use, and spelling, so the first and foremost recommendation of this research is creating awareness among students. They must be made aware of their actual position so that the rectifications can follow accordingly. For example, teachers can discuss their answer scripts with students. Class test should also be analyzed and mistakes should be explained to students so that they can 
avoid the same mistakes in their future course of examinations.

A bridge-course can be recommended dealing with all the basic segments like capitalization, punctuation, grammar/language use, and spelling. For example, there is no placement test conducted at NU. Bridge course will help students to bring the same level before jumping to main syllabus.

Teachers must explain the rules of capitalization and make students practice them in the classroom. For example, exercises like title ones and identification of capital and lower case exercises can help rectify the capitalization errors of the students.

Teachers must explain the use of all the punctuation marks and observe that students use them accurately. For example, exercises like reading aloud a newspaper with accurate punctuation awareness and editing writing pieces with punctuation errors can help students in improving this segment.

All the major grammatical rules should be explained to the students to maximize their usage. Both inductive and deductive approaches must be followed as per the requirements of the students. Exercises like form and functions exercises, story writing exercises etc. can also help students in enhancing their grammatical credentials.

In spelling, for example, exercises like dictating new words, word completion exercises and word formation exercises can go a long way in enhancing students' spelling awareness. They can also use spelling games like flash cards, clueless crossword, word scramble, letter blocks, word search, crossword bouncing letters etc. One cannot deny the importance of phonemic transcription while teaching spelling to students as mentioned in Alsaawi (2015, p. 57) that, "Successful English spelling performance involves the processes of segmenting the spoken word into its phonemic components and then selecting the appropriate graphemes to represent the phonemes". Group-brainstorming on a given topic, i.e. students work cooperatively and write down all the ideas that come to their mind in connection with a topic. Later, then they can organize them in order to tackle the problem of coherence and cohesion.

Descriptive writing on a wide variety of topics of their interest like football, about themselves, their family, their country, their cultural things, traditions, religion etc. can hugely enhance their creative writing. "When students write about topics of their interests, this motivates them to keep reading and selecting what is significant to them even if they encounter difficulties" (Al Badi, 2015, p. 71). So students must be motivated to write on the topics of their interest in order to provide them a kind of platform to horn their writing skills. .

There can also be some general but effective recommendations for enhancing the writing skills. Writing classrooms should be focused on maximum writing practice rather than delivering passive lectures. Teachers should rely on learner centered approach rather than teacher centered approach.

The researchers, in their six years of teaching experience in Saudi Arabia, have personally observed that even descriptive paragraphs are memorized and then exactly reproduced in exams. That fails the very purpose of writing and is a huge impediment in enhancing their writing skills. Students should be encouraged to write paragraphs on their own thereby expressing their ideas freely. They must be oriented on how to use discourse markers in their paragraphs so that they can write well constructed and logical paragraphs. "Discourse markers are used to link between the ideas in the written text showing addition, examples, comparison and contrast, time, place or direction, and they indicate logical relationship" (Rass, 2015, p. 51).

The traditional practice of memorization must be discontinued. The examination pattern must be changed. The same topic paragraphs shouldn't be repeated. At least one examination paper must be external. The universities which are running same syllabus can cooperate with each other in exchanging their examination paper. It will encourage students to study their subject thoroughly rather than memorizing the expected items in the examination. Moreover, it will also make teachers more accountable. Students should be discouraged in joining private tutors outside university rather they should be motivated to visit concerned teachers during their office hours for any academic issue.

Use of audio-visual aids can make the classroom fun and interesting instead of the usual boredom of lectures. For example, teachers can show students a picture and ask them describe it. Teachers can also use short movie clips in order to ignite the imaginative faculty of students and then ask them to guess the rest part of the movie and write it.

Teachers should think about innovative ways of making the classroom interesting and desirable. Games and other interesting internet-based materials can enhance the process of language learning. For example, lots of materials based on writing skills are available on the internet. Teachers can exploit them for the benefits of students. 
Listening and writing integrated activities are also recommended to improve spelling errors. In such activities, students will listen to error prone words with the sounds like ' $p$ ' ' $t$ ' etc.

Teachers should motivate students to maintain their personal diary. It will encourage them to pen down their experiences in their own language that will further improve their writing skill.

Last, but not the least, students should always be motivated for language learning. The teachers should make the learners visualize the futuristic benefits of having a command over English language. Teachers should emphasize the huge range of career-oriented benefits of EFL in various professional courses like medical, engineering, pharmacy etc. This will help sustain the interest of the students thereby minimizing their difficulties in learning EFL in general and writing in particular.

\section{Conclusion}

Without a solid basis of the formal linguistic system, students cannot hope to develop into effective EFL learners in general and writers in particular. The approach outlined emphasizes the discursive and cognitive aspects of the development of the writing skill.

With many years of teaching EFL in Saudi Arabia, the researchers agree with the findings of many research studies which conclude that once students are writing fluently and confidently, they will be more inclined and able to write accurately. The recommendations outlined above and the general framework of reference may provide an invigorating effect on writing practices and contribute to the development and reinforcement of the students' confidence in EFL in general and writing in particular.

If given a chance, the researchers will further design some remedial activities to improve these four areas of writing as they are already familiar with the root causes in forms of errors committed by students. In further study, the researchers will also try to design some task based activities to improve all problem areas of students in writing skill. The researchers will also try to design some effective skill integrated activities to develop writing competence among students and hence enable them to minimize errors in writing by practicing real life situation based activities.

\section{Acknowledgements}

This project has been funded by the Deanship of Scientific Research, Najran University, grant No. NU/SHED/13/014.

\section{References}

Abdul Haq, F. (1982). An analysis of syntactic errors in the composition of Jordanian Secondary Students (Unpublished master's thesis). Jordan, Yarmouk University.

Al Badi, I. A. H. (2015). Academic writing difficulties of ESL learners. The 2015 WEI International academic conference proceedoings. Barcelona, Spain. Retrieved from http://files.eric.ed.gov/fulltext/EJ1079082.pdf

Al Murshidi, G. (2014). UAE university male students' interests impact on reading and writing performance and improvement. English Language Teaching, 7(9), 57-63. http://dx.doi.org/10.5539/elt.v7n9p57

Al-Jarf, R. (2010). Spelling errors corpora in EFL. Sino-US English Teaching, 7(1), 6-15. Retrieved from http://www.finchpark.com/KNUFLE/book-1/unit06/Spelling-error-corpora-EFL.pdf

Alsaawi, A. (2015). Spelling errors made by Arab learners of English. International Journal of Linguistics, 7(5), 55-67. http://dx.doi.org/10.5296/ijl.v7i5.8446

Bacha, N. N. (2002). Developing Learners' Academic Writing Skills in Higher Education: A Study for $\begin{array}{lllll}\text { Educational Reform. Language \& } \quad \text { Education, } & 16(3),\end{array}$ http://dx.doi.org/10.1080/09500780208666826

Bebout, L. J. (1985). An Error Analysis of misspellings made by learners of English as a first and as a second language. Journal of Psycholinguistic Research, 14, 569-593. http://dx.doi.org/10.1007/BF01067386

Bjork, L., \& Raisanen, C. (1997). Academic Writing: A University Writing Course. Lund, Sweden: Studentlitteratur.

Calhoun, E. F. (2002). Action research for school improvement. Educational Leadership, 59(6), 18-24. Retrieved from http://educationalleader.com/subtopicintro/read/ASCD/ASCD_408_1.pdf

Cordewener, K. A., Bosman, A. M., \& Verhoeven, L. (2015). Implicit and explicit instruction: The case of spelling acquisition. Written Language \& Literacy, 18(1), 121-152. http://dx.doi.org/10.1075/wll.18.1.06cor

Crystal, D. (2003). English as a Global Language. Cambridge: Cambridge University Press. 
http://dx.doi.org/10.1017/CBO9780511486999

Fageeh, A. I. (2011). EFL learners' use of blogging for developing writing skills and enhancing attitudes towards English learning: An exploratory study. Journal of Language and Literature, 2(1), 31-48.

Hashim, H. H. (2011). Peer feedback with checklists in writing classes: Saudi learners' and teachers' attitudes and receptions (Unpublished master's thesis). King Saud University, Riyadh. Retrieved from http://repository.ksu.edu.sa/jspui/bitstream/123456789/19286/1/\%D8\%A7\%D9\%84\%D8\%B1\%D8\%B3\% D8\%A7\%D9\%84\%D9\%87.pdf

Javid, C. Z., \& Umer, M. (2014). Saudi EFL learners' writing problems: A move towards solution. Proceeding of the Global Summit on Education GSE 2014, 4-5 March 2014. Kuala Lumpur. Malasiya. Retrieved from http://worldconferences.net/proceedings/gse2014/toc/papers_gse2014/G\%20078\%20-\%20CHOUNDHARY \%20ZAHID\%20JAVID_Saudi\%20EFL\%20Learners_\%20Writing\%20Problems\%20A\%20Move\%20towar ds\%20Solution_read.pdf

Jung, T., Osterwalder, H., \& Wipf, D. (2000). Teaching and Assessing Middle-Year Students' Speaking and Listening Skills. Teaching and Learning Research Exchange. Retrieved from http://www.mcdowellfoundation.ca/main_mcdowell/projects/research_rep/52_teaching_assessing.pdf

Khan, I. A. (2011). Diagnosis of Learning Difficulties in English: The Arabic Bilingual Context. Elixir Psychology, 36, 3448-3454. 3 Retrieved from http://www.elixirpublishers.com/articles/1350545453_36\%20(2011)\%203448-3454.pdf

Lado, R. (1957). Linguistics across Cultures. Ann Arbor: University of Michigan Press.

Rass, A. R. (2015). Challenges face Ararab students in writing well-developed paragraphs in English. English Language Teaching, 8(10), 49-59. http://dx.doi.org/10.5539/elt.v8n10p49

Ridha, N. S. (2012). The effect of EFL learners' mother tongue on their writings in English: An error analysis study. Journal of the College of Arts, 60, 22-45. Retrieved from http://www.iasj.net/iasj?func=fulltext\&aId $=58267$

Zughoul, M. (1984). The Linguistic Attitudes of Arab University Students: Factorial Structure and Intervening Variables (In Arabic). J. the Jordanian Academy of Arabic, 25-26, 148-200. http://dx.doi.org/10.1515/ijsl.1984.50.155

\section{Appendix A}

\section{Difficulties of Learning EFL in KSA: Writing Skills in Context}

Name:

Academic Number:

\begin{tabular}{|c|l|c|c|c|c|c|}
\hline S. No. & $\begin{array}{c}\text { Scale: } 5=\text { Always, 4= Usually, } \\
3=\text { Sometimes, 2= Rarely, } \\
1=\text { Never, }\end{array}$ & $\begin{array}{c}5 \\
\text { Always }\end{array}$ & $\begin{array}{c}4 \\
\text { Usually }\end{array}$ & $\begin{array}{c}3 \\
\text { Sometimes }\end{array}$ & $\begin{array}{c}2 \\
\text { Rarely }\end{array}$ & \begin{tabular}{c} 
Never \\
\hline 1
\end{tabular} \\
\hline 2 & Do you face problems in capitalization & & & & & \\
\hline 3 & $\begin{array}{l}\text { Do you face problems in punctuation } \\
\text { language use problems in grammar/ }\end{array}$ & & & & & \\
\hline 4 & Do you face problems in spelling & & & & & \\
\hline
\end{tabular}

Thanks for your cooperation! 


\section{Appendix B}

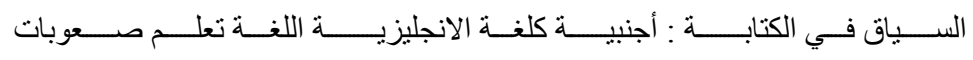

\begin{tabular}{|c|c|c|c|c|c|c|}
\hline \multirow[t]{5}{*}{ 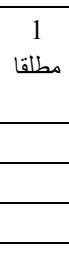 } & نادرا & 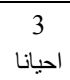 & 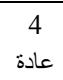 & $\begin{array}{ll}5 \\
\text { دائما }\end{array}$ & 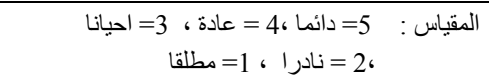 & المسلسل \\
\hline & & & & & هل لديك مشاكل فى استخدام الحروف الكبيرة & 1 \\
\hline & & & & & هل لديك مشاكل فى استخدام علامات الترقيم & 2 \\
\hline & & & & & هل تو اجه اى مشاكل فى استخدام القو اعد/استخدام اللغة & 3 \\
\hline & & & & & هل تو اجه اي مشاكل فى الهجاء & 4 \\
\hline
\end{tabular}

$$
\text { شكرا على تعاونكم }
$$

\section{Copyrights}

Copyright for this article is retained by the author(s), with first publication rights granted to the journal.

This is an open-access article distributed under the terms and conditions of the Creative Commons Attribution license (http://creativecommons.org/licenses/by/3.0/). 